\title{
The Conception of Managing Innovation Process While Forming "Traditional" Model of Innovative Development of Economy
}

\author{
Saule Abaibekovna Rakhimova ${ }^{1}$ \\ ${ }^{1}$ Омsк Sтате University n.a. F.M. Dostoevskiy, Omsk, Russia \\ Correspondence: Saule Abaibekovna Rakhimova, мsк Sтате University n.a. F.M. Dostoevskiy, 644077, Omsk, \\ Russia.
}

Received: October 6, 2014 Accepted: December 13, 2014 Online Published: February 12, 2015

doi:10.5539/ass.v11n5p324 URL: http://dx.doi.org/10.5539/ass.v11n5p324

\begin{abstract}
Conceptual and categorical apparatus of innovation process and managing innovation process is introduced in the article. The works of different scientists on innovations, innovation theory approaches and innovative development are reviewed here. Different approaches of Kazakh, Russian and foreign scientists toward innovative processes and their management are analyzed in the article. The article provides the conception of managing innovation process. The basic advantages and differences of the author's approach are introduced here. Managing through emphasizing meso-objects is also offered here. Meso-level formed on the basis of technological effectiveness and submeso-level with subtypes of economic activities are singled out. The analysis of manufacturing industry structure of the Republic of Kazakhstan is made here. The share of average low-tech, low-tech, average high-tech and high-tech types of manufactures in the total value of innovative production is calculated and introduced. The conception of innovative activity is revealed. The conclusions that the concentration of innovative activity is higher in average high-tech and high-tech types of production are made and they've proved that it is necessary to develop innovations in these very types of production. From the point of behavioral aspects these types are also to be stimulated. On the bases of applying this technique bottlenecks and incentives with anti-incentives, entering and managing innovative process developing mainly high-tech types of production can be revealed. Using integration approach it was offered to form regional innovative clusters at the expense of which innovation process can be activated and it will allow forming "traditional" model of innovative development of economy. The proposed integrated approach allows eliminating a number of problems and activates innovation process that in whole will lead to building new models of innovative development of economy in developed and developing countries due to the factors of "input" into innovation process.
\end{abstract}

Keywords: management, innovation process, managing innovation process, the concept of managing innovation process, degree of technological effectiveness, innovative activity concentration

\section{Introduction}

Major number of scientific works of Kazakhstani, Russian and foreign researches are devoted to innovative economy, theory, methodology and approaches to innovation process. However, at present, effective launching and realization of innovation processes are revealed only in the form of several attempts. The problem is in the lack of scientifically grounded approach towards solving of this issue. As we conceive it is necessary to offer the conception of managing innovation process. The idea of the conception is in understanding and applying new approaches to management that would form innovation process considering prior directions of further development and due to all these it will help to form innovation clusters applying integration process. This very approach will start forming "traditional model" of innovation development of economy owing to progressive management of innovation process.

The founders of the theory of innovation whose works became a foundation for researches made by national experts of Organization for Economic Cooperation and Development and further formalized into Frascati Family Manuals (OESD, 2002, 2005) were K. Pavitt (2003), J. Schumpeter (1934), J. Dossi (1990), P. Drucker (1995), B. A. Lundvall (1988, 1992), D. Medous, etc. (Rothwell, 1994; Mensch, 1975; Mahdi 2002). 
Initially innovation as a process was studied by Hartmann Haustein, Lapin V. N., F. Valenta, B. Santo, F. Nickson, Medynsky V. G., Zavalin P. N., Valdaitsev S. V., Mamyrov N. K., V. Rappoport, B. Twiss, Glazyev S. Yu.

Golichenko O. G., Ivanova N. I., Dynkin A. A., Polterovich V. M., Samovoleva S. A., Glazyev S. Yu., Gohberg L. M. etc. studied innovation process applying systemic approach, fulfilled researches in the field of national innovation system development and national innovation policy.

Innovation process on the level of an enterprise was studied by Shmanyev S. V., Zavlin P. N., Yakovets Yu. V., Kiku, Piatetsky V. Ye., Medynsky V. G., Prerva O. L. Kozlovskaya E. A., Demidenko D. S., Yakovleva Ye. A. etc.

Pchelintsev O. S., Glazyev S. Yu, Granberg A. G., Shchepina I. N., Yakovets Yu. N. devoted their works to studying innovation process on local, regional levels.

Shchepina I. N., Golichenko O. G., Balychyeva Yu. Ye. studied innovation process applying statistic and econometric approaches on the level of an enterprise and on a regional level.

As we see it, despite the fair contribution into the theory and methodology of innovation processes the issue of managing innovation process is still researched insufficiently. In connection with this challenge we offer the conception of managing innovation process.

\section{Methods}

The conception of managing innovation process offers a new system of views towards managing this process. Its difference from other approaches is in management through:

- Activation of "input" factors;

- Managing the innovation process itself;

- Managing innovation process for forming the innovative development of economy model.

Our conception understands management as a complex framework approach which allows separate stages of innovation process together with micro-, meso- and macro-levels as the subjects of innovation process to develop comprehensively. It also helps to construct models of innovation economy development.

At the very beginning it is necessary to work out a trajectory, a strategy of development, considering the factors of "input" into innovation process. For this purpose on the basis of thorough analysis meso-objects with the peculiarities of forming innovation process should be singled out. Then we form or correct basic directions of meso- and macro-level policy and work out the measures for managing innovation process taking the selected meso-objects into consideration. Further we form clusters of innovation process and work out integration approach. Let's study all abovementioned in detail.

\section{Results}

To distinguish factors of "input" into innovation process, we must define priority directions managing which one will be able to activate innovation process. Owing to the development of high-tech production developed countries made significant progress. In this connection we are to explore the possibilities and innovative potentials of different types of production.

1. Define meso-levels - high-tech, middle-tech and low-tech production.

2. Define submeso-level.

So we get the following:

1) concentration of innovative activity according to the degree of technological effectiveness:

- The number of output that fall on high, average-high, average-low and low-tech production.

- The share of output in high-tech, average- high, average-low and low-tech production to the whole value of industrial output.

2) the categories of innovative output according to the type of economic activity and the degree of technological effectiveness:

- Newly introduced product or the one that underwent through significant technological changes (product innovation);

- Product that underwent improvement (product innovation); 
- Other innovative products (process innovation).

As the result we get the behaviour of high-tech, average high-tech, average low-tech and low-tech enterprises:

- Winning new markets;

- Strengthening of the former positions;

- Minimizing production costs on previous markets.

3. On the basis of selected and further analized submeso-levels we get the indicators:

- Sectoral shifts indicator;

- Innovative behaviour indicator.

4. On the basis of these indicators we can find growing point and bottlenecks.

5. On the basis of bottlenecks we form basic directions of managing innovation processes in these meso-objects.

6. Having elaborated these directions we offer measures for managing innovation processes in this meso-objects.

It is important to mention that every stage of above-mentioned algorithm requires right managerial decisions. Just that very decision must lead to activation of innovation process and innovative product manufacturing that, in whole, will bring to innovative development.

Meso-level is defined by the degree of technical effectiveness: high-tech, average high-tech, average low-tech and low-tech types of production; submeso-level - these are subtypes of economic activity.

The first step should be based on economic and statistical approach. Let's study the given methods by the example of the Republic of Kazakhstan (the statistic data are extracted as of 2012) (Statistic Digest of the Republic of Kazakhstan Agency on Statistics, 2013).

Having analyzed meso-level relying on statistic data published in statistic digests of The Republic of Kazakhstan Agency on Statistics we obtained the following results:

- $\quad 95.3 \%$ of total value of innovative output falls on manufacturing industry;

- Share of products sold from low-tech types of production takes $10.14 \%$;

- Specific weight in innovative output is taken by average low-tech types of production that makes $64.2 \%$;

- Average high-tech type of production is represented by chemical industry products that is $7.59 \%$;

- $\quad$ High-tech types of production make $18.7 \%$.

Table1 shows the share of innovative products by the types of production.

Table 1 . The share of innovative products by the type of productions

Newly introduced output or the one that underwent significant technological changes, which 75,67\% includes:

Average low-tech types of production

$44,13 \%$

High-tech types of production make

$16,92 \%$

Low-tech types of production make

Average high-tech types of production - production of chemical industry

$7,17 \%$.

Products that underwent significant improvement, including:

$6,24 \%$

Average low-tech production

Low-tech types of production

High-tech types of production

Average high-tech types of production - chemical industry production output

$0,41 \%$

Other innovative products including

Average low-tech production 
Having made the calculations we came to conclusion that among innovative products sold specific weight goes to average low-tech types of production (the third stage) $-64.20 \%$. The second place is taken by high-tech types of production with $18,07 \%$. And the third place goes to low-tech types of production with $10.4 \%$. As for average high-tech types of production they take the last place with $7.59 \%$.

With the purpose to define concentration of innovative activity and to reveal types of production that mainly support the development of innovation processes it is necessary to calculate types of production in the total value of domestic manufacturing.

Leading position in total value of domestic manufacturing is taken by average low-tech types of production with $65.61 \%$. However, in this case the second place is taken by low-tech types of production that makes $18.13 \%$. The third place is for high-tech types of production with their $8 \%$. And the last place is taken by average high-tech types of production $-3.95 \%$.

Having calculated concentration of innovative activity one can conclude that to manage innovation processes it is vitally important to expand average high-tech and high-tech types of production as these sectors have a strong concentration of innovative activity.

Average low-tech types of production are developing fairly well and to expand these sectors a little effort is necessary to undertake as the index is practically equal to 1 viz 0.98 .

In low-tech types of production the index is 0.56 .

In average high-tech types it is 1.92 .

And in high-tech types it is 2.26 .

Considering the received calculations one may conclude that average high-tech and high-tech production are profitable to expand as concentration of innovations is higher and in case of expansion these spheres will get the highest level of innovative development.

Low-tech types are to be contracted as there is a weak concentration of innovations.

Let's analyze the categories of innovative output according to the types of economic activity and the degree of technological effectiveness.

Products newly introduced or those that undergone significant technological changes make specific weight of the whole innovative products i.e we can say about product innovation with the share in total value of innovative products of $75.67 \%$. The second place with $18.09 \%$ is taken by other innovative products which we may refer to as process innovation. Products that underwent improvement made $6.24 \%$. In table 2 we can examine it in sections.

Table 2. The range of innovative production broken down by the types of economic activity and the degree of technological effectiveness

The share of newly introduced and undergone significant technological changes products in total 75,67\% value of innovative output including:

Average low-tech types of production

$75,67 \%$

High-tech production

$44,13 \%$

Low-tech types of production

$16,92 \%$

Average high-tech production

$7,44 \%$

$7,17 \%$

Other innovative products (process innovation)

18,083

Average low-tech

17,22

High-tech

Low-tech

0,41

Average high-tech

0,003

Products that underwent improvement including:

6,23

Average low-tech

$2,84 \%$

High-tech

0,7

Low-tech 
As a result in Table 3 we may trace the behaviour of high-, average high-, low- and average low-tech types of production.

All these types of production are basically tuned on winning new markets.

Table 3. The behaviour of high-, average high-, low- and average low-tech types of production

\begin{tabular}{|c|c|c|}
\hline \multicolumn{3}{|c|}{ Low-tech types of production } \\
\hline $\begin{array}{l}\text { Newly introduced products or the one that } \\
\text { underwent significant technological changes }\end{array}$ & $73,4 \%$ & $\begin{array}{l}\text { In this case they are directed basically on } \\
\text { product and advanced innovations. }\end{array}$ \\
\hline Products that underwent improvement & $22,5 \%$ & \\
\hline Other innovative products. & $4,08 \%$ & \\
\hline \multicolumn{3}{|c|}{ Average low-tech types of production } \\
\hline $\begin{array}{l}\text { Newly introduced or significantly technologicaly } \\
\text { changed products }\end{array}$ & $68,74 \%$ & $\begin{array}{l}\text { Here we may see that specific weight is } \\
\text { represented by product and process }\end{array}$ \\
\hline Improved products & $4,43 \%$ & innovations \\
\hline Other innovative products & $26,83 \%$ & \\
\hline \multicolumn{3}{|c|}{ Average high-tech types of production } \\
\hline $\begin{array}{l}\text { Newly introduced products and the products that } \\
\text { underwent significant technological changes }\end{array}$ & $94,53 \%$ & $\begin{array}{l}\text { In this case specific weight is represented by } \\
\text { product and advanced innovations. }\end{array}$ \\
\hline Improved products & $5,43 \%$ & \\
\hline Other innovative products & $0,04 \%$ & \\
\hline \multicolumn{3}{|c|}{ High-tech types of production } \\
\hline $\begin{array}{l}\text { Newly introduced products or to the products that } \\
\text { underwent significant technological changes }\end{array}$ & $93,64 \%$ & $\begin{array}{l}\text { In this case specific weight is represented by } \\
\text { product and advanced innovations. }\end{array}$ \\
\hline Improved products & $3,86 \%$ & \\
\hline Other innovative products & $2,50 \%$ & \\
\hline
\end{tabular}

Having analyzed the data horizontally we came to conclusion that considering behaviour aspect one should stimulate high-tech and average high-tech types of production. They, in the most degree, tend to win new markets. Innovative behaviour indicator makes us come to such conclusion. Among high-tech types of production $93.64 \%$ falls on newly introduced output and among average high-tech types of production this indicator equals $94.53 \%$.

Innovative behaviour indicator was figured out on the bases of selected and analyzed submeso-levels.

Sectoral shift indicator we receive on the basis of vertical analysis (Rakhimova, 2013; Golichenko, 2011).

Thus, on the basis of carried out analyses one may conclude that average high-tech and high-tech types of production became meso-objects.

On the basis of the received results of abovementioned analysis it is possible to form incentives and anti-incentives towards innovative activity together with the conditions of input into innovation process in these meso-objects. This, in its turn, will signal to take measures on decreasing or annihilating anti-incentives and manage different levels with due regards for factors which support positive forming of innovation processes and innovation production.

On the level of enterprises: it is necessary to increase innovative orientation on cooperation with middle and large enterprises, R\&D results should be brought into manufacturing process, on the basis of available potentials they must aim at production of middle and high-tech output.

The factors that define entering into innovation process for any enterprise can be internal, directly involved into innovation process and vitally important for it and external that influence on its fulfillment.

Knowledge, staff, intellectual property, finance, infrastructure and strategy are referred to internal factors.

Internal factors, these are conditions that help to operate:

- Demand that answers such issues as why someone needs innovation process and if it will still be on demand in the end; 
- Presence of supporting financial and tax policies, openness of an external environment to innovation process i.e. readiness to cooperation and partnership, high innovative literacy and perceptiveness of the market;

- Lack of obstacles for innovative entrepreneurship;

- High competition that helps the development of the enterprise through applying innovations.

On regional level, input into innovation process means: sufficient presence of innovators and diffusers; maturity of high and average high-tech production; tendency to cooperation and partnership of subjects of innovation process; market demand for innovations (internal, external, one that depends on the degree of marketing and organizational innovations) etc.

Anti-incentives (barriers, risks) will allow working out the policy on regional and republican level and strategy on the level of the enterprise.

\section{Discussions}

The distinguishing feature of it comparing to other approaches is in the idea that managing is performed through: first, activating factors of "input", second, managing innovative process, third, managing innovation process for forming innovative development of economy. The approaches different academics have towards managing innovation process are connected with: innovation process and small innovative entrepreneurship (Gribkova, 2005); processes of managing innovation and sustainable development of contemporary organizations (Mechantseva et al., 2012); managing innovations and strategy of innovation development (Nizhegorodtseva, 2007); organizing and improving management of integrated systems (Kudrova \& Orekhov, 2009); analyzing the problems of managing innovation process (Alishauskas, 1990); starting, disseminating and utilizing innovations on the market in the form of technologies, products and services that demand modernization of management on the basis of innovations (Chechurina, 2010). It is necessary to note that in each approach management is performed by separate subjects, separate innovation stages and separate component of innovation process. In the conception that we offer management is understood as a complex systemically important approach which allows developing separate stages of innovation process, micro-, meso- and macro-levels as subjects of innovation process and structuring the model of innovative development of economy. The results can be the following:

- on the micro-level: the share of innovatively active enterprises will increase, the volume of manufactured and sold innovative products, private commercial goals will be achieved;

- on the meso-level: regional innovative systems will be developing, regions will increase their activity, all the stages of innovation process will be carried out through development of regional innovative clusters, manufactured production will become competitive, the share of innovative products in GRP (Gross Regional Product) will increase;

- on macro-level: innovative development of the economy will be achieved.

In whole all abovementioned measures together with competent management will allow the Republic of Kazakhstan to move into a new model of innovative development where innovative indicators will be high, all regions will use their innovative potential effectively and successfully multiply it, all stages of innovation process will be formed and activated and innovative products will be manufactured.

It will help the Republic (now with high-tech competitive products) enter the world market and take leading positions among innovative countries.

\section{Conclusions}

It is necessary to work out strategies and mechanisms of managing innovation processes of the enterprises, organizational mechanisms and forms of management on the micro level; to set role functions and to limit high-, middle- and low-tech productions; to strengthen, in case of open innovations, cooperation between small, middle and large enterprises.

On the regional level: it is necessary to support forming of regional innovation system, to work out regional innovative strategy and policy, to form meso-objects on the basis of framed principles and indicators, to manage regional innovation processes for raising regional innovative rating. It will speed innovation process and help to work out strategy for single-type regions, to work out regional development policy depending on the degree of forming and progressing of innovation process.

On the macro level: it is necessary to work out state policy and mechanisms of managing innovation processes.

It is vitally important to form input into innovation process, into the process of innovative production in average high-tech and high-tech types of production on every level. 
From our point of view it will be more rational to manage sorted out meso-objects having formed innovative clusters considering "input into innovative process" and applying integration approach.

Innovative clusters can be formed as supersystem i.e. available regional clusters can be transformed into innovative one. But, in this case, innovative cluster will be formed on technological effectiveness principle i.e., average high-tech and high-tech. Integration approach will support forming innovative clusters. Integration can be classified according to:

- $\quad$ Subjects (state, regional, scientific, sectoral, educational, educational, financial, personnel policies);

- $\quad$ Legislative and regulatory framework, programs and development strategies;

innovation process stages (The Law of the Republic of Kazakhstan: Legislative framework on Innovations of the Republic of Kazakhstan, 2012; The Law of the Republic of Kazakhstan "On Science", 2011; The Law of the Republic of Kazakhstan "On Education", 2014; National Program of Forced industrial and innovative development of the Republic of Kazakhstan, 2010; Address of the President of the Republic of Kazakhstan, Leader of the Nation, N.Nazarbayev to the Nation "Strategy "Kazakhstan-2050": New Political Course of the Established State", 2012; Strategy of Innovative and Industrial Development of the Republic of Kazakhstan for 2003-2015, 2003; The conception of Innovative Development of the Republic of Kazakhstan till 2020, 2012; Address of the President of the Republic of Kazakhstan N.Nazarbayev to the nation "Kazakhstan's way - 2050: common aim, common interests, common future". - January 17, 2014; Karenov, 2014). This integration is vitally important as a real "picture" of innovative model of economic development will be outlined at the very beginning.

It is obvious that integration process is rather complex, long-lasting and antinomic. Basically, it is defined by the lack of common interests, in other words, when every part is functioning separately solving only limited circle of tasks. However, due to integration between subjects of innovation process regional clusters will be formed; conditions for strengthening cooperation between small, medium and large businesses will be created; interrelation chains between scientific organizations, authorities and businesses will be built. As a result, necessary prerequisites for new business-models will be created and they will be built on principles of open innovations. From our point of view integration will help innovation process run effectively and will support innovative development of the country. If one can create such innovative clusters extensively it will lead to "traditional" model of innovative development in the future where all stages of innovation process will be presented in every priority sector.

The algorithm of reaching positive results is illustrated below.

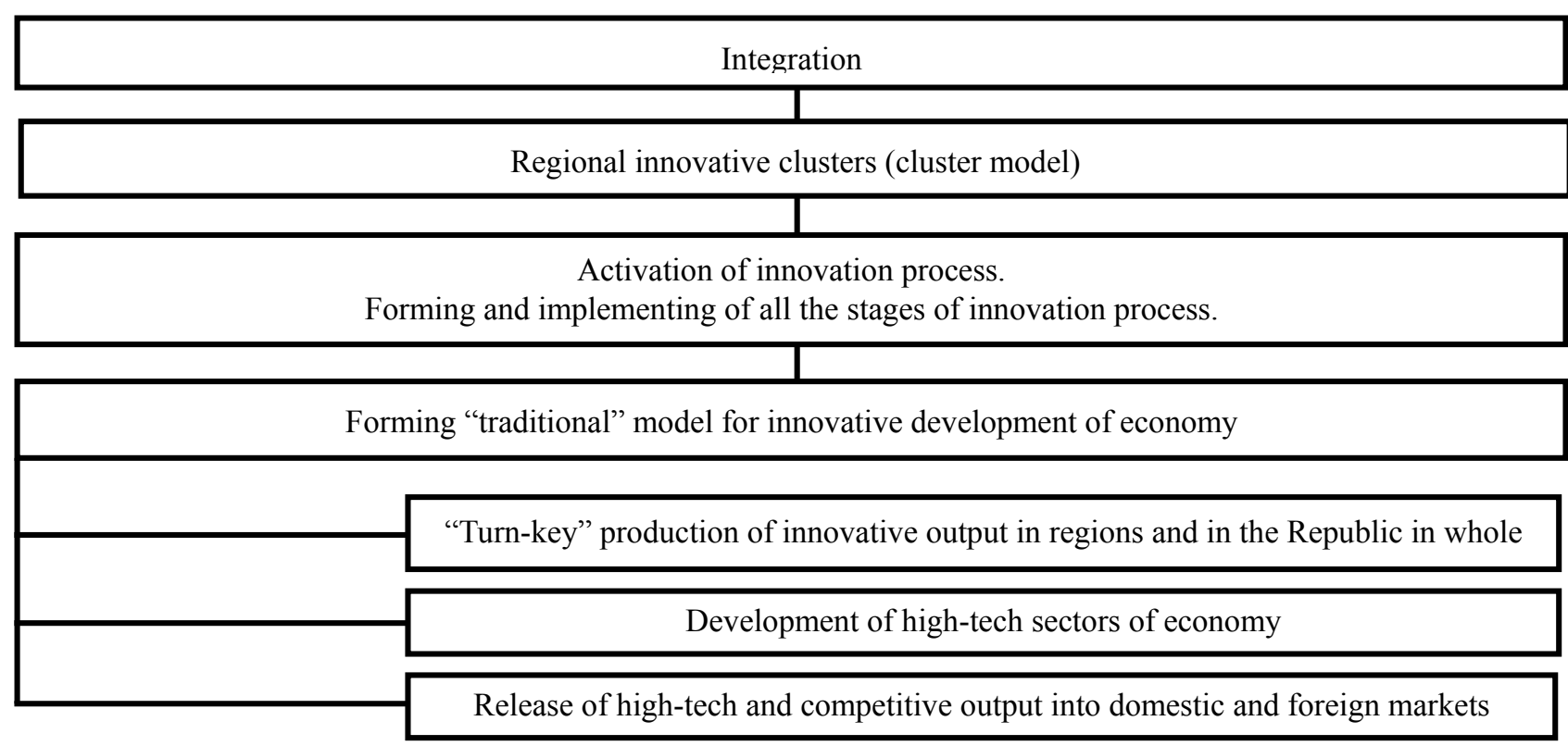

Figure 1. Algorithm of forming "traditional" model for innovative development of economy. [worked out by the author] 
Forming innovative clusters will help to develop additional opportunities and open innovative horizons.

Sum it up, considering the results of applying the conception of managing innovation process, we may conclude that:

- It will allow managing innovation process effectively with new understanding of managing innovation process in practice;

- In theory, it will allow revealing theoretical and methodological regulations of managing innovation processes on micro-, meso-, macrolevels;

- In science it will help to apply new complex methodological approach based on the method of economic and statistic multilevel analysis of innovation process.

In conclusion I would like to underline with great appreciation that the author's position was significantly influenced by the scientific dialogue with Doctor of Economics, professor, member of Expert Councils at Russian Scientific Foundations, Golicheno O. G.

\section{References}

Address of the President of the Republic of Kazakhstan N.Nazarbayev to the nation "Kazakhstan's way - 2050: common aim, common interests, common future". January 17, 2014

Address of the President of the Republic of Kazakhstan, Leader of the Nation, N.Nazarbayev to the Nation "Strategy "Kazakhstan-2050": New Political Course of the Established State". 14 February 2012

Alishauskas, J. J. (1990). (Ališauskas) Problemy upravleniya innovatsionnym protsessom. Vilnius.

Chechurina, M. N. (2010). Managing innovation process in multilevel economic system. ST. Petersburg.

Dosi, G. et al. (1988). Technical Change and Economic Theory. London.

Drucker, P. (1995). Innovation and Entrepreneur ship (p. 546). N. Y.

Freeman, C., \& Socte, L. (1990). New Explorations in the Economics of Technological Change (p. 213). London.

Golichenko, O. G. (2011). Basic Factors of National Innovative System Development. M.: Nauka.

Gribkova, I. V. (2005). Managing innovation processes (by the example of small innovative entrepreneurship).

Karenov, R. S. (2014). Prioriteti i tendencii razvitiya menedjmenta v perspektive -Kniga tretya,_ Monografiya. -Karaganda-Izdat._poligraf. centr Kazahstansko-Rossiiskogo universiteta-2014. 376 s

Kudrova, N. A., \& Orekhov, S. A. (2009). Integrative mechanisms of management.

Legislative framework on Innovations of the Republic of Kazakhstan: The Law of the Republic of Kazakhstan No. 534-IV dated 9 January 2012 "On State Support for Industrial and Innovative Activities".

Lundvall, B. (1988). Innovation as an Interactive Process: from User-Producer Interaction to the National System of Innovation. In G. Dosi, C. Freeman, R. Nelson, G. Silverberg, \& L. Soete (Eds.), Technical Change and Economic Theory (pp. 349-369). London: Frances Pinter.

Lundvall, B. A. (1992). National Systems of innovation (p. 67). London.

Mahdi, S. (2002). Search Strategy in Product Innovation Process: Theory and Evidence from the Evolution of Agrochemical Lead Discovery Process (Unpublished D. Phil Thesis). SPRU, University of Sussex, England.

Mechantseva, K. F., Yurkov, A. A., \& Karpova, O. K. (2012). Economic modelling of processes for managing modern organizations in aspects of innovative and sustainable development. Rostov on Don.

Mensch, G. (1975). Das Technologische Patt: Innovationen überwinden die depression. Frankfurt am Main: Umschau. Verlag.

National Program of Forced industrial and innovative development of the Republic of Kazakhstan dated 19 March 2010 approved by the Decree of the President of the Republic of Kazakhstan No. 958

Nizhegorodtseva, R. M. (2007). Managing innovations and strategy of innovative development of Russia. V.: Dobroye Slovo.

OSLO Manual: Proposed Guidelines for Collecting and Interpreting Technological Data (2002, 2005). Paris: OESD.

Pavitt, K. (2003). The process of innovation. - Science and Technology Policy Research the Freeman Centre 
University of Sussex Brighton. - England.

Rakhimova, S. A. (2013). The Development of Innovations in Kazakhstan Industries: Analyses Based on Technological Degree. Collected Works on the Materials of XX International Correspondent Scientific and Practical Conference "Innovations in Modern World", M.

Rothwell, R. (1994). Towards the Fifth-generation Innovation Process. International Marketing Review, 11(1), $7-31$.

Schumpeter, J. (1934). The Theory of Economic Development. Cambridge, Massachusetts: Harvard Univ. Press,

Science and Innovative activity of Kazakhstan 2008 - 2012. (2013). Statistic Digest of the Republic of Kazakhstan Agency on Statistics.

Strategy of Innovative and Industrial Development of the Republic of Kazakhstan for 2003-2015 dated 13 May 2003 No.1096

The conception of Innovative Development of the Republic of Kazakhstan till 2020, Astana, 2012.

The Law of the Republic of Kazakhstan "On Education" (with changes and amendments as of 18 February 2014) No. 319-III dated 27 July 2007

The Law of the Republic of Kazakhstan "On Science” No. 407-IV 3PK dated 18 February 2011.

\section{Copyrights}

Copyright for this article is retained by the author(s), with first publication rights granted to the journal.

This is an open-access article distributed under the terms and conditions of the Creative Commons Attribution license (http://creativecommons.org/licenses/by/3.0/) 